Article

\title{
What Factors Influence the Sustainable Tour Process in Social Media Usage? Examining a Rural Mountain Region in Pakistan
}

\author{
Talib Hussain ${ }^{(D)}$, Benqian Li * and Dake Wang ${ }^{(D)}$ \\ School of Media and Communication, Shanghai Jiao Tong University, Shanghai 200240, China; \\ talibhussian@sjtu.edu.cn (T.H.); dakewang@sjtu.edu.cn (D.W.) \\ * Correspondence: libenqian@sjtu.edu.cn
}

Received: 26 May 2018; Accepted: 23 June 2018; Published: 28 June 2018

\begin{abstract}
This research demonstrated a significant method for measuring tourist behavior in terms of social media use for rural mountain region tourism. This study proposed a quantitative method for establishing tourists' main activities during the travel process when using social media. This study is potentially unique in its application of a predominantly mathematical analysis to measure tourist intentions, which until now have been evaluated mainly on the basis of qualitative analyses. It is now possible to quantitatively measure the activities and ambitions of tourists in rural mountain region tourism. The data was collected from different respondents in the area of Gilgit-Baltistan (GB), Pakistan. The researchers visited different areas in GB and interviewed the tourists who use social media for tourism. The results of study showed that the majority of tourists are more interested in using social media at the planning stage. Thus, this study contributes to the literature in the sense that it provides a mathematical and statistical model to measure tourist intentions in sustainable rural mountain region tourism.
\end{abstract}

Keywords: social media; tourist behavior; sustainable rural mountain region tourism; Analytic Hierarchy Process (AHP) evaluation model and index system; Gilgit-Baltistan; Pakistan

\section{Introduction}

The main objective of this study is to provide practical and theoretical contributions for quantitatively measuring tourist behavior in rural mountain region tourism. In the literature, many studies have been conducted to measure tourist behavior and investigate the role of social media, but there is a lack of information connecting the role of social media as it relates to rural mountain region tourism. Additionally, this study is significant in that it formulates a mathematical and statistical model that uses an analytic hierarchy process model (AHP) to measure tourist intentions toward social media use at each stage of tourism; this is the first time that such a model has been used in this field.

AHP was developed as a technique for organization and analysis based on mathematics, but its application has received credit in many sectors that require complex decision-making, especially in the fields of business and social sciences [1]. More recently, AHP has also been used in complex decision-making processes that require the evaluation of several components, as well as quantitative evaluations, and evaluations regarding long-term impact and/or high stakes [2]. In some studies, $\mathrm{AHP}$ has been used to learn about tourist behavior directed toward finding a destination $[3,4]$. $\mathrm{AHP}$ has also been used to solve the most salient determinants in selecting a destination for tourism. However, the usage of AHP in these studies has been limited due to a focus on general tourist destinations [5]. In another study, AHP was used to learn the set of key indicators along with 
weightings for tourist attractions in Taiwan, and develop a quality management self-evaluation mechanism for tourism businesses that enhanced its application [6]. Therefore, this study is potentially unique in its application of a predominantly mathematical analysis of the measurement of social media usage in the tourism process, which has thus far been evaluated mainly on the basis of qualitative analyses. In short, this study employs a method of deriving ratio scales from paired comparisons through matrices. Input can be obtained from actual measurements, such as price and weight, or from subjective opinions, such as satisfaction and preference [7]. Based on these previous studies, it is clear that the use of AHP in tourism is applicable, and most importantly, the use of AHP is very significant in measuring the ambitions of tourists within the whole tour process for a rural mountain area visit.

\section{Subject of Innovation-What Is New in This Study?}

This study is unique in nature and in its contribution to the literature, theory, and practices (namely, it is the first attempt to formulate a mathematical model using an AHP to measure tourist intentions of using social media in the tour process for rural mountain region tourism). Across the world, there are diverse ways to measure the factors affecting tourists' attitudes toward social media usage for trips and tours [8]. It is not easy to establish factors sufficiently to measure tourists' attitudes toward the usage of social media for choosing and using tourism goods and services. No such model can be found in any of the previous studies. Previous studies have mostly depended on qualitative tools and analysis techniques to measure factors affecting tourist behavior. In this study, the AHP model was used to measure the relative priority of these intangible issues/factors. Some researchers have used the AHP model in two phases: first, to collect information, and then to rank the data using hierarchy comparison matrices [9]. In this study, after collecting the data and establishing the factors affecting tourist attitudes toward social media usage, 40 expert respondents were invited to compare these elements/factors in the hierarchy through comparison matrices. These 40 experts were respondents/tourists who were supposed to have knowledge of this comparison technique. The respondents were asked to compare the elements with the use of social media in tourism. The AHP has been applied in previous studies for such complex decision-making situations [10]. This method uses a set of pairwise comparison matrices with a nine-point scale that shows the comparative importance of two intangible components. To construct a quantitative model, the importance of the factors was measured in a first step; then, it was divided into different layers. Finally, the tourist social media usage theory evaluation model was developed for the rural mountain region tourism process.

\section{Literature Review}

\subsection{Social Media and Its Current Forms}

Social media is a term that refers to internet-based and mobile-based online communications that help people connect and search for information as part of an online community [11]. Social media is mainly associated with user-generated content, Web 2.0, Social Networking Sites, and virtual worlds [12-14]. With the onset of social media, especially Facebook, YouTube, and WeChat, millions of people per hour began to share their views online via messaging, video sharing, and other online communication [15]. Facebook alone counts 1.06 billion monthly active users, who collectively share and upload millions of data contents per hour on a daily basis [16]. In China, there are an estimated 300 million active users of online communication on different sites [17]. To understand the evolution of current social media, an overview of the history of social media development is essential.

In 1979, Usenet was introduced by Tom Truscott and Jim Ellis at Duke University [18]. Usenet was a global online system that allowed users to publicly post their ideas online [19]. However, the current form of social media goes back two and half decades to when Bruce and Susan Abelson introduced Open Diary [20]. During the same era 20 years ago, the term "weblog" was also used and adopted widely by online users [21]. The most important period in the field was the moment when the internet 
became accessible to most people through the use of high-speed connections; this development led to the creation of two of the more famous SNSs in 2003 and 2004: Myspace and Facebook, respectively [12].

\subsection{Social Media and Tourism}

Much work has been conducted to discern the role of social media in rural tourism. To link social media in tourism and for rural tourism, this study discusses the different contributions by tourists and businesses that operate especially in a tourism context.

Tourism takes different directions when it comes to rural tourism, including awareness, education, social interaction, economic contributions, and social change, on the condition of local community involvement [22]. To boost rural tourism, social media is considered a first choice, with the potential for a great impact on attracting tourists [23]. Previous studies have shown a strong relationship between social media and rural tourism, where tourism has a positive impact on the social and economic conditions of rural areas [24]. Tourists mainly choose different destinations in rural regions due to social media advertisements [25].

Social media plays a vital role when searching for information and selecting a travel destination, along with tourist decision-making at all stages of a tour or trip [26]. The use of social media by consumers has enabled the tourism industry to enter a new era [27]. Due to the significant role played by social media in forming consumer attitudes toward rural tourism, many countries in the world have paid particular attention to the promotion of social media in their societies. Tourist behavior has changed completely due to the availability of social media [28]. Social media has enabled tourists to find concise information [29]. In terms of tourism, social media usage has a direct impact [30], since each tourist has specific intentions, and is looking for control over his or her activities [31]. Social media use allows tourists to control their activities [32].

Also, the rapid advancement of technology and the consumer-internet connection has brought about a revolutionary change in the tourism sector [33]. Due to the abundance of information on the internet, consumers need to be able to find relevant and sufficient information in order to make better decisions in a timely manner [34]. The availability of various web tools has made tourists independent and given them multiple alternatives in terms of choices of places to visit [35]. As to why social media is used here to measure tourist behavior, it is largely due to a sense of insecurity; these days, searching for information on websites seems risky, so tourists prefer or trust social media and other media applications more $[3,36]$. The greater amount of data that is available on different websites can also create problems for the optimal use of such resources [37].

Overall, this study was conducted with the view that mass media, and especially social media, can contribute to rural mountain region tourism [38]. Communities and the people who live in rural areas, and in developing countries in particular, are constantly faced with information traffic problems affecting decision-making [39]. Media communication plays the role of an agent to boost the flow of information and improve decision-making [40]. Mass media can also easily reach people in remote communities [41]. This study revealed that social media contributes directly to rural tourism in various stages that differ according to the different ways/stages in which tourists and consumers use social media.

\subsection{Tourism in Rural and Mountain Regions}

The term "tourism" is derived from the concept of travel outside of the existing environment [42]. Tourism may be for pleasure or for business [43]. Tourism is the actual practice of touring, including the tourism sector, which provides all of the facilities, entertainment, and accommodation for the tourists, among other things [44]. Tourism includes national and international sectors, and affects the economies of both the source and host nations [45]. In addition to the basic principles and definitions, tourism refers to the fleeting movement of the public outside of their environment, with some ambition to get information, entertainment, or economic benefit [46]. 
In the literature, many terms are used to describe tourists, including "travelers", "excursionists", and "visitors". All of these terms justify one concept with slight differences [47]. A tourist is a person who has the special target of viewing places, capturing locations on camera, interacting with local people culturally, and experiencing local traditions through economic activities [48]. The literature states that the word "tourism" was first used in 1811, and the word "tourist" was used in 1838 [49]. A foreign tourist was defined as a person who is supposed to have stayed or traveled for at least $24 \mathrm{~h}$ outside of the home environment; this definition was amended by the United Nations in 1945 to include a maximum stay of six months for a foreign tourist [50].

After the 1990s, rural tourism entered into a new phase [51]. This development gave new directions to rural policy development and new roles for advancement [52]. Researchers define rural tourism in different ways, with some considering it to be green tourism, ecotourism, or farm tourism [53]. These different concepts of rural tourism also helped to spread tourism and extend its definition [54]. Some other researchers state that the different faces of tourism allow for further specification of the rural world, as well as the development of broad concepts, such as rural world and rural ecosystem [55]. With today's busy lifestyles, rural tourism offers shelter to all kinds of people; human beings search for opportunities to escape their busy lives by spending some time in a place where they can relax and enjoy themselves [56].

There is no globally agreed-upon definition of a mountain or mountain region. Nearly all countries define mountain regions by referencing their countries' geography and locations. A common and acceptable way to define a mountain and mountain region was proposed by the United Nations Environment World Conservation Monitoring Centre (UNEP-WCMC), which uses the GTOPO30 digital elevation model (DEM) of the United States (US) Geological Survey [57]. According to this system, mountain regions are categorized according to height calculated in meters. This definition evinces that the study area of Gilgit-Baltistan, Pakistan is entirely mountainous; therefore, tourism in Gilgit-Baltistan can be included in rural mountain region tourism [58] (Figures 1 and 2).

\section{Materials and Methods}

The use of social media in the tour process has become the first choice of tourists. The majority of tourists view social media as a serious decision-making tool. Based on the tourist intentions to use social media for rural mountain tourism, the following research objectives were focused:

\subsection{Research Objectives}

- To propose a quantitative method for determining tourist intentions when using social media in rural mountain region tourism.

- To quantitatively determine social media usage behavior at each stage of the tour process.

- To find the most important stage in which tourists use social media within the tour process.

\subsection{Research Background and Rationalization of the Study Type}

In the literature, it was found that most studies focused on one or more aspects of the tour process (planning, pre-trip, trip, and post-trip) to discern the function of social media, and that these studies were mainly qualitative [59]. Few previous studies focused on this issue to inform tourists of their behavior throughout the tour process. In one study, it was found that users wish to use social media in the pre-trip and post-trip stages of a tour, as well as during the tour itself, because of the trust that they place in social media [60]. In a second study, certain comprehensive details are presented to determine tourist behavior at different stages of a tour qualitatively [26]. Aside from these studies, there are some other studies that attempt to explain the use of social media in the tour process, but their applications regarding knowing a specific tour feature/step are limited. The main limitation of these studies is that they are unable to conduct quantitative investigations at all stages of a tour; namely, the first study 
only covers the pre-trip, trip, and post-trip stages [60], and the second study only presents a qualitative analysis [26].

\subsection{Methods of the Study}

To measure the quantitative thematic factors and formulate a mathematical model, this study was conducted on the basis of the findings within the literature and a qualitative investigation, which was conducted to discern the thematic contents preferred by tourists when using social media during all stages of tourism. The qualitative investigation enabled the researcher to discern the main themes, and provided a basis for formulating a mathematical model to quantitatively measure tourist behavior.

After conducting interviews, analyses were conducted using qualitative data analysis techniques (coding, sorting, sifting, tabulations, etc.). This stage helped the researcher to discern the themes that were highlighted by tourists at each stage of a trip (planning, pre-trip, trip, and post-trip). Table 1 shows the Excel sketch that was used to tally the main outcomes of the interviews from 124 respondents. The respondents were chosen on the basis of the cluster-based sampling method. The details regarding study target area and sampling are discussed in the following sections.

Table 1. Coding of Interviewee Responses.

\begin{tabular}{|c|c|c|c|c|c|c|c|c|c|c|c|c|}
\hline \multirow{2}{*}{$\begin{array}{l}\text { Stage } \\
\text { No. }\end{array}$} & \multirow{2}{*}{ Themes } & \multirow{2}{*}{ Final Codes } & \multicolumn{10}{|c|}{ Respondents Codes (up to Only 10 for Illustration) } \\
\hline & & & R1 & $\mathbf{R} 2$ & R3 & R4 & R5 & R6 & R7 & R8 & R9 & R10 \\
\hline \multirow{3}{*}{1} & \multirow{3}{*}{$\begin{array}{l}\text { Planning } \\
\text { stage }\end{array}$} & Information Search & 1 & 1 & 2 & 2 & 2 & 2 & 1 & 1 & 2 & 2 \\
\hline & & $\begin{array}{l}\text { Looking at other people's } \\
\text { comments about a tour }\end{array}$ & 3 & 2 & 3 & 3 & 1 & 1 & 2 & 2 & 3 & 3 \\
\hline & & $\begin{array}{l}\text { Calculating the budget for } \\
\text { the trip }\end{array}$ & 2 & 3 & 1 & 1 & 3 & 3 & 1 & 3 & 1 & 1 \\
\hline \multirow{3}{*}{2} & \multirow{3}{*}{$\begin{array}{l}\text { Pre-trip } \\
\text { stage }\end{array}$} & $\begin{array}{l}\text { Finding and collaboration with } \\
\text { travel party members }\end{array}$ & 2 & 2 & 2 & 1 & 1 & 2 & 1 & 2 & 1 & 3 \\
\hline & & Handling trip departure issues & 1 & 1 & 1 & 2 & 3 & 1 & 2 & 1 & 2 & 2 \\
\hline & & $\begin{array}{l}\text { Booking tickets and } \\
\text { making purchases }\end{array}$ & 3 & 3 & 3 & 3 & 2 & 3 & 1 & 3 & 2 & 1 \\
\hline \multirow{4}{*}{3} & \multirow{4}{*}{$\begin{array}{l}\text { During } \\
\text { the trip } \\
\text { stage }\end{array}$} & Self-Expression & 1 & 1 & 3 & 3 & 3 & 3 & 1 & 1 & 1 & 1 \\
\hline & & Selecting the best options & 4 & 2 & 2 & 2 & 2 & 4 & 1 & 2 & 3 & 3 \\
\hline & & Entertainment & 2 & 3 & 4 & 1 & 1 & 1 & 2 & 2 & 2 & 4 \\
\hline & & $\begin{array}{l}\text { Keeping in touch with family } \\
\text { and friends }\end{array}$ & 3 & 4 & 1 & 4 & 4 & 2 & 2 & 1 & 4 & 2 \\
\hline \multirow{4}{*}{4} & \multirow{4}{*}{$\begin{array}{l}\text { Post-trip } \\
\text { stage }\end{array}$} & $\begin{array}{l}\text { Keeping in touch with travel } \\
\text { party members }\end{array}$ & 1 & 3 & 1 & 1 & 1 & 1 & 1 & 1 & 2 & 4 \\
\hline & & Evaluating past consumption & 2 & 1 & 2 & 4 & 4 & 4 & 1 & 2 & 4 & 1 \\
\hline & & Relating trip adventures & 3 & 2 & 3 & 3 & 3 & 2 & 2 & 3 & 2 & 2 \\
\hline & & Recall memories & 4 & 4 & 4 & 2 & 2 & 3 & 2 & 3 & 4 & 4 \\
\hline
\end{tabular}

On the basis of the results of the qualitative investigation and literature review, a ranking study was conducted using the AHP model to formulate a mathematical and statistical model to measure tourist intentions toward social media usage at each stage of the trip. This model is unique and applicable to further studies and innovations. The newly formulated mathematical model also helped the researchers to discern the social media functions at each stage of a tourist's trip, and most importantly, served as a quantitative measurement for social media functions in the traveler's process.

\subsection{Model for Evaluating Tourist Intentions in the Tour Process}

In this study, after collecting the data and depicting the factors that affect tourist attitudes toward social media usage, 40 expert respondents/tourists were invited to compare these elements/factors in the hierarchy through comparison matrices. These 40 experts were respondents who were supposed 
to have subject knowledge of this compression technique. First, these tourists were trained to use the AHP hierarchy through comparison matrices, and then were asked to compare the variables according to their views.

Population and Sampling of the Study

The study population belongs to the Gilgit-Baltistan area of Pakistan. Figure 1 shows the geography of the study population on the map of Pakistan.

Gilgit-Baltistan is the most well-known tourism region in Pakistan [61]. Every year, many tourists from all over the world visit this area to enjoy mountain adventures [62]. Gilgit-Baltistan borders Khyber Pakhtunkhwa province to the west, Azad Kashmir of Pakistan to the south, the Wakhan of Afghanistan to the north, the Tashkurgan (Xinjiang) region of China to the east and northeast, and Kashmir to the southeast [63].

The study sample encompasses the eight districts of Gilgit-Baltistan, Pakistan: Gilgit, Skardu, Astore, Diamer, Ghizer, Ghanchi, Hunza, and Nager. A probability cluster sampling method was used to collect the data. The whole province was divided into districts/clusters, and the data was collected accordingly.

Figure 2 shows the different districts of Gilgit-Baltistan, which covers an overall area of 72,971 $\mathrm{km}^{2}$. The population of Gilgit-Baltistan [64] was estimated in 2015 to be 1,800,000. The most famous tours and tourism regions in Gilgit-Baltistan are the valleys of Naltar, Bagrote, Hunza, Ghizer, Kargah, Duikar, Hopar, Passu, and Shigar, among others [62,65]. These areas are the most well-known as national and international tourist destinations. Aside from these locations, the whole of Gilgit-Baltistan is naturally gifted with mountainous regions that are suitable for tours and tourism. Tourists are attracted to these regions by the richness of their natural resources, but they also come for a closer look at the culture and to experience other adventures, such as hunting and climbing $[38,66]$.

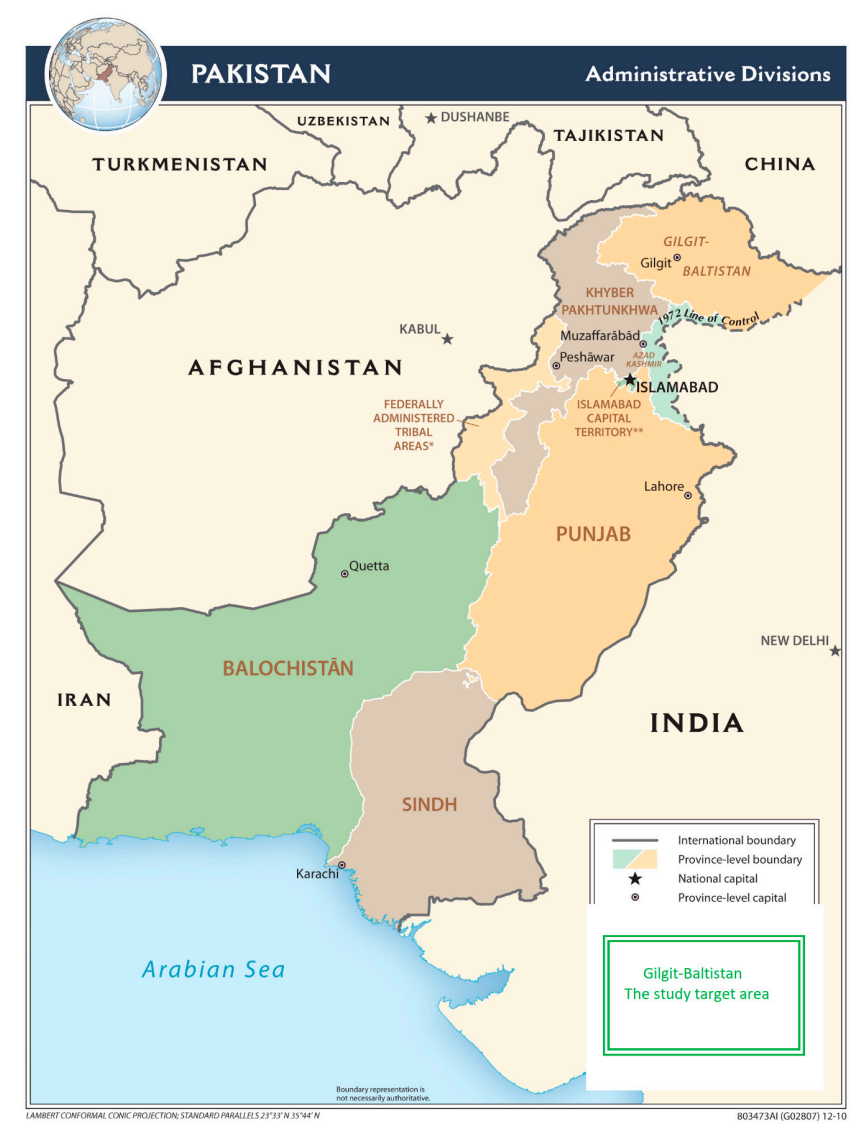

Figure 1. Map of Pakistan focusing on the study area [61]. 


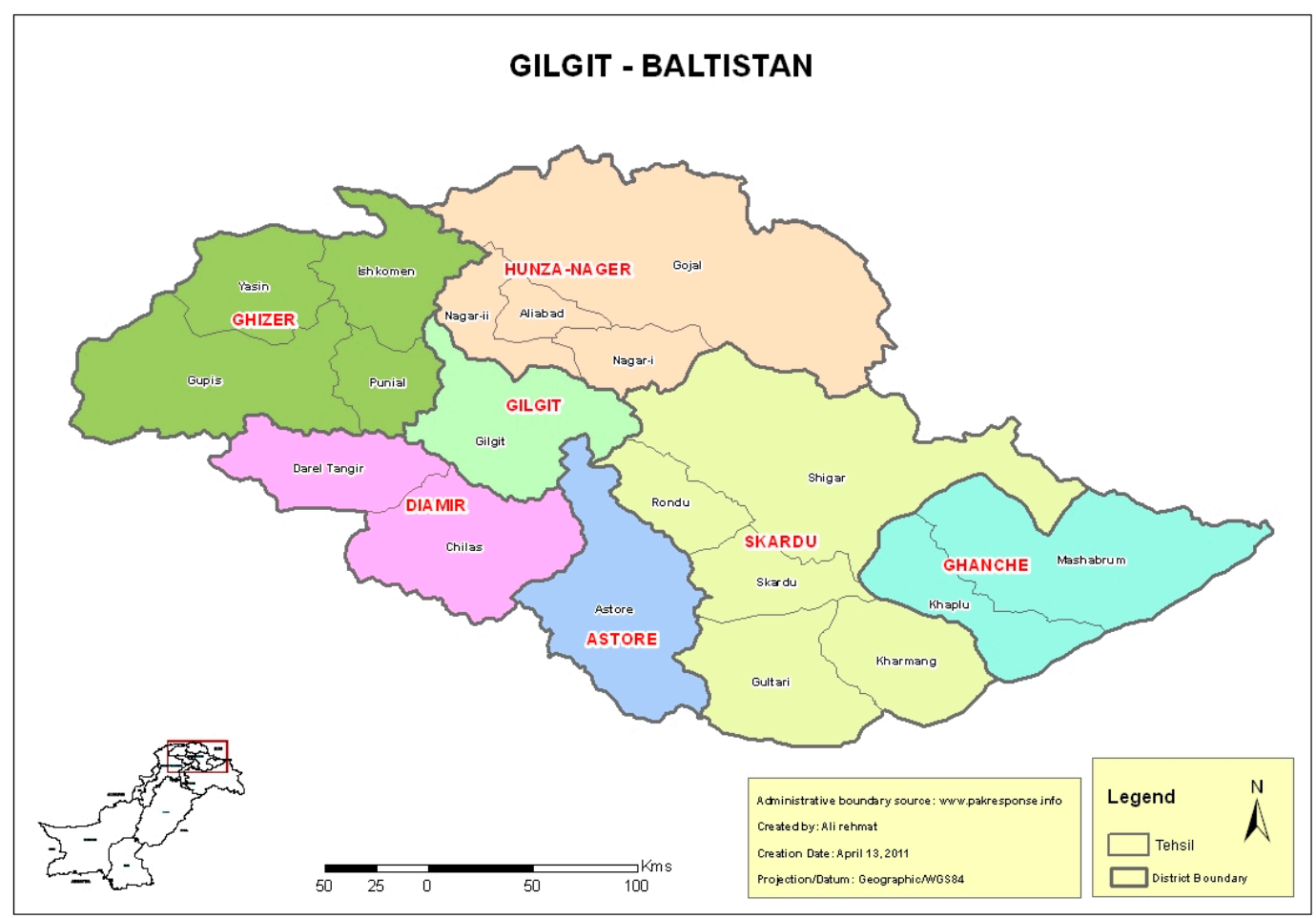

Figure 2. Gilgit-Baltistan districts [62].

The respondents were asked to compare the elements by building indices of tourist intentions in rural mountain region tourism. The AHP has been applied in previous studies for similar, complex decision-making situations $[10,67]$. This method uses a set of pairwise comparison matrices with a nine-point scale that shows the comparative importance of two intangible components. To construct a quantitative model, the importance of the factors was measured in a first step, and then divided into different layers. Finally, the social media usage theory evaluation model was developed for the tourism process.

\subsection{Methods to Construct the Factors/Intentions}

In order to evaluate the factor/intention with the most effect on the tour process for tourists using social media, dependent and independent variables were initially defined. The tourist intention was defined as the dependent variable, while the planning, pre-trip, trip, and post-trip stages were defined as independent variables and treated as mid-level factors in the indices for AHP modeling. To measure each independent variable, sub-constructs were defined and treated as low-level factors in the AHP model, as explained here.

\subsubsection{Explanation of the Constructs and Concepts}

- Planning stage (Y1)

Social media use at the planning stage may consist of collecting information on tourism, looking at other people's comments about a place, and calculating a budget. The qualitative study and previous literature showed that consumers are very interested in checking their peers' comments about a trip. This type of search provides in-depth knowledge and insight on a destination $[59,68]$. 
- Pre-trip stage (Y2)

The literature review and qualitative study results showed that at this stage, the main intentions of tourists are to find friends with whom they can collaborate, manage trip affairs, book tickets, and purchase goods and services for the trip [59].

- During the trip stage (Y3)

The use of social media during the trip is very interesting. Tourists show insight in using social media throughout the trip through user-generated contents [69]. The main activities undertaken by tourists at this stage include: self-expression, selecting the best options, entertainment, and keeping in touch with family and friends [59]. During the trip, tourists enjoy sharing photos and new experiences with their families and travel companions $[38,70]$.

- Post-trip stage (Y4)

An interesting use of social media by tourists occurs at the end of the trip. The main activities performed by tourists using social media at the end of the trip include: keeping in touch with travel companions, evaluating past consumption, relating trip adventures, and recalling memories [59].

\subsubsection{Calculation of Keys and Elements}

(1) Dependent variable level

- $\quad$ Tourist intentions $(X)$

(2) Independent variables (mid-level)

- $\quad$ Planning stage (Y1)

- $\quad$ Pre-trip stage (Y2)

- $\quad$ During the trip stage (Y3)

- $\quad$ Post-trip stage (Y4)

(3) Low-level factors

- $\quad$ Searching for information (Z1)

- Looking at other people's comments about a tour (Z2)

- Calculating the budget for the trip (Z3)

- $\quad$ Finding and collaborating with travel party members (Z4)

- Handling trip departure issues (Z5)

- $\quad$ Booking tickets and making purchases (Z6)

- $\quad$ Self-expression (Z7)

- $\quad$ Selecting the best options (Z8)

- $\quad$ Entertainment (Z9)

- Keeping in touch with family and friends (Z10)

- Keeping in touch with travel party members (Z11)

- Evaluating past consumption (Z12)

- $\quad$ Relating trip adventures (Z13)

- $\quad$ Recalling memories (Z14)

\section{Analytic Hierarchy Process}

For ranking and comparing the matrices, the AHP method was used. A total of 40 trained respondents were invited to rank the factors using a nine-point scale method. Table 2 shows the association of $i$ and $j$, which clears the nine-point scale method. 
Table 2. Resultant Matrix Scale and Ranking Techniques for Judgment Scale Matrix.

\begin{tabular}{clc}
\hline No & Rank & Aij \\
\hline 1 & $i$ and $j$ are equally important & 1 \\
2 & $\boldsymbol{i}$ is a little more important than $j$ & 3 \\
3 & $\boldsymbol{i}$ is obviously more important than $i$ & 5 \\
4 & $\boldsymbol{i}$ is much more important than $\boldsymbol{j}$ & 7 \\
5 & $\boldsymbol{i}$ is very much more important than $\boldsymbol{j}$ & 9 \\
6 & $\boldsymbol{i}$ is a little less important than $\boldsymbol{j}$ & $1 / 3$ \\
7 & $\boldsymbol{i}$ is obviously less important than $\boldsymbol{j}$ & $1 / 5$ \\
8 & $\boldsymbol{i}$ is much less important than $\boldsymbol{j}$ & $1 / 7$ \\
9 & $\boldsymbol{i}$ is very much less important than $\boldsymbol{j}$ & $1 / 9$ \\
\hline
\end{tabular}

\subsection{Construct Judgment Matrices}

After taking the average of 40 experts' score, the matrices were constructed as follows:

(1) Resultant matrix of Z1, Z2, and Z3 with respect Y1 (planning stage)

$$
\mathrm{d} 1=\left[\begin{array}{ccc}
1 & \frac{51}{3} & \frac{54}{5} \\
\frac{3}{51} & 1 & 5 \\
\frac{5}{54} & \frac{1}{5} & 1
\end{array}\right]
$$

(2) Resultant matrix of Z4, Z5, and Z6 with respect to Y2 (pre-trip stage)

$$
\mathrm{d} 2=\left[\begin{array}{ccc}
1 & 5 & \frac{52}{2} \\
\frac{1}{5} & 1 & \frac{42}{9} \\
\frac{2}{52} & \frac{9}{42} & 1
\end{array}\right]
$$

(3) Resultant matrix of Z7, Z8, Z9, and Z10 with respect to $\mathrm{Y} 3$ (during the trip)

$$
\mathrm{d} 3=\left[\begin{array}{cccc}
1 & \frac{61}{5} & \frac{54}{5} & \frac{45}{96} \\
\frac{5}{61} & 1 & 6 & \frac{53}{4} \\
\frac{5}{54} & \frac{1}{6} & 1 & \frac{51}{4} \\
\frac{96}{45} & \frac{4}{53} & \frac{4}{51} & 1
\end{array}\right]
$$

(4) Resultant matrix of Z11, Z12, Z13, and Z14 with respect to Y4 (the post-trip)

$$
\mathrm{d} 4=\left[\begin{array}{cccc}
1 & 6 & \frac{51}{2} & \frac{47}{8} \\
\frac{1}{6} & 1 & 5 & 6 \\
\frac{2}{51} & \frac{1}{5} & 1 & \frac{52}{9} \\
\frac{8}{47} & \frac{1}{6} & \frac{9}{52} & 1
\end{array}\right]
$$

(5) Resultant matrix of $Y 1, Y 2, Y 3$, and $Y 4$ with respect to $X$ (the entire trip)

$$
\mathrm{d} 5=\left[\begin{array}{cccc}
1 & \frac{53}{8} & \frac{53}{8} & \frac{55}{9} \\
\frac{8}{53} & 1 & \frac{45}{8} & \frac{51}{2} \\
\frac{8}{53} & \frac{8}{45} & 1 & \frac{53}{5} \\
\frac{9}{55} & \frac{2}{51} & \frac{5}{53} & 1
\end{array}\right]
$$

\subsection{Reliability and Consistency of the Study}

The calculations for the ordering vector of every eigenvector, $W$, corresponding to its maximum distinctive root, $\lambda \max$, are based on the following criteria. 
(i) Equation to measure the resultant matrix geometric mean of all of the elements of each row

$$
\mathrm{W}^{\prime}=\left(\mathrm{W}_{1}^{\prime}, \mathrm{W}^{\prime}{ }_{2}, \mathrm{~W}^{\prime}{ }_{3}, \ldots, \mathrm{W}_{\mathrm{n}}^{\prime}\right)^{T}=\left(\sqrt[n]{\prod_{j=1}^{n} \mathrm{a}_{1 \mathrm{j}}}, \sqrt[n]{\prod_{j=1}^{n} \mathrm{a}_{2 \mathrm{j}}}, \ldots, \sqrt[n]{\prod_{j=1}^{n} \mathrm{a}_{\mathrm{nj}}}\right)^{T}
$$

(ii) For standardization of each element of the vector $\mathrm{W}^{\prime} \mathrm{W}=\left(\mathrm{w}_{1}, \mathrm{w}_{2}, \mathrm{w}_{3}, \ldots, \mathrm{w}_{\mathrm{n}}\right)^{T}=$

$$
\left(\frac{w_{1}^{\prime}}{\sum_{i=1}^{n} w_{i}^{\prime}}, \frac{w_{2}^{\prime}}{\sum_{i=1}^{n} w_{i}^{\prime}}, \ldots, \frac{w_{n}^{\prime}}{\sum_{i=1}^{n} w_{i}^{\prime}}\right)^{T}
$$

(iii) Calculation of maximum eigenvalue $\lambda \max$. The resultant matrix $=\lambda \max =\sum_{i=1}^{n} \frac{(A W)_{i}}{n w_{i}},\left(A W_{i}^{\prime}\right)$ It is the $i$ th element of vector $A W$

(iv) Consistency check index toward resultant matrix validity check

$$
\mathrm{CI}=\frac{\lambda \max -\mathrm{n}}{n-1}
$$

(v) For more information and random consistency ratio index

$$
\mathrm{CR}=\frac{C I}{R I}(n \geq 2)
$$

Through the above equations and by using the calculations of the results of the study, the consistency can be checked. The matrix will be consistent and valid if $\mathrm{CR}<0.10$. Table 3 presents the average consistency index random values that also depict the differences conferred to the various orders of the matrix [71]. The comparison matrix values were entered into MATLAB to see the difference in the result of the numerical computation of the eigenvalue and eigenvector value compared with the results of this study. Following the AHP method, the researcher measured the consistency ratio values for every judgment matrix; it was confirmed that all of the judgment matrices fulfill the consistency check, and the results are reliable for further decision-making.

Table 3. Average Consistency Index.

\begin{tabular}{ccccccccccc}
\hline $\mathbf{N}$ & $\mathbf{1}$ & $\mathbf{2}$ & $\mathbf{3}$ & $\mathbf{4}$ & $\mathbf{5}$ & $\mathbf{6}$ & $\mathbf{7}$ & $\mathbf{8}$ & $\mathbf{9}$ & $\mathbf{1 0}$ \\
\hline $\mathrm{RI}$ & 0 & 0 & 0.58 & 0.9 & 1.12 & 1.24 & 1.32 & 1.41 & 1.45 & 1.49 \\
\hline \multicolumn{1}{c}{ Note: Source, Thomas L. [71]. }
\end{tabular}

\subsection{Theoretical Evaluation Models for Social Media Usage in Tourism Process}

Following on from previous literature with similar studies, the mathematical equations has been developed [2]. Based on the impact values and factor levels, the mathematical equation for calculating tourist intentions was composed as:

Set $\mathrm{t}^{3} \mathrm{i}(=1,2, \ldots, 14)$ is the final point for 14 factors.

$$
w_{i j}^{2}, w_{i j}^{1}(i=1,2 \ldots m ; \quad j=1,2, \ldots, n)
$$


Using this formula, if the relative impact value of $i$ in the middle or lowest level is compared to $i$ in this level, and $m$ are $n$ are the total number of factors in this level and the level beneath it, respectively, then the score of the $k$ th level relative to $(k+1)$ th level can be computed as:

$$
t_{i}^{k}=\sum_{j=1}^{n} w_{i j}^{k+} 1_{t} k_{j}+1(k=3,2,1 ; i=1,2,3, \ldots m)
$$

After calculating the values for every level/stage of tourism, the following model can be used to measure the overall tourists' tour intentions in rural mountain tourism:

$$
W=\frac{1}{10} \sum_{i=1}^{3} t_{i}^{1} \times 100 \%
$$

Here

$$
t_{1}^{1}, t_{2}^{1}, t_{3}^{1}, t_{4}^{1}
$$

Stands for the ranking values for the planning stage (Y1), pre-trip stage (Y2), trip stage (Y3), and post-trip stage (Y4) relative to tourist intentions toward rural mountain region tourism. $W$ is the total score of tourist intentions toward a specified rural mountain region tour.

\section{Final Decisions by Positioning the Factors with Impact Values}

By compiling the survey results and computed values, the factors that were supposed to influence tourist intentions in the planning, pre-trip, trip, and post-trip stages were ranked. Tables $4-8$ show the ranking results that were calculated based on the previous results of weighted results. These tabulated values are further used in the final decision-making process.

Table 4. Final Decision Impacting Values for Planning Stage of the Tour Process.

\begin{tabular}{cc}
\hline Using Social Media in Planning Stage & Impact Values \\
\hline To search for information on tourist destinations & 0.7984 \\
Looking at other people's comments about a tour & 0.1473 \\
To calculate the budget for the trip & 0.0544 \\
\hline
\end{tabular}

Table 5. Final Decision Impacting Values for Pre-Trip Stage of the Tour Process.

\begin{tabular}{cc}
\hline Using Social Media in Pre-Trip Stage & Impact Values \\
\hline To find and collaborate with travel party members & 0.811 \\
To handle trip departure issues & 0.1566 \\
To book tickets and make purchases & 0.0324 \\
\hline
\end{tabular}

Table 6. Final Decision Impacting Values for Trip Stage of the Tour Process.

\begin{tabular}{cc}
\hline Using Social Media during the Trip & Impact Values \\
\hline For self-expression & 0.5838 \\
To select the best options & 0.2511 \\
For entertainment & 0.1207 \\
To keep in touch with family and friends & 0.0444 \\
\hline
\end{tabular}


Table 7. Final Decision Impacting Values after a Mountain Region Trip.

\begin{tabular}{cc}
\hline Using Social Media after a Mountain Region Trip & Impact Values \\
\hline To keep in touch with travel party members & 0.5744 \\
To evaluate past consumption & 0.259 \\
To relate trip adventures & 0.1117 \\
To recall memories & 0.0549 \\
\hline
\end{tabular}

Table 8. Final Decision Impacting Values for Tourist Intentions Overall.

\begin{tabular}{cc}
\hline Stages & Impact Values \\
\hline Planning stage (Y1) & 0.482 \\
Pre-trip stage (Y2) & 0.2286 \\
Trip stage (Y3) & 0.2444 \\
Post-trip stage (Y4) & 0.045 \\
\hline
\end{tabular}

Table 4 shows the impacting values for the variables/activities of tourists in the planning stage of the tour process for rural mountain region tourism. The results reveal that the factor with the most impact on the planning stage of the tour process has a value of 0.7984 , thereby showing that a majority of tourists want to use social media in the planning stage of their rural mountain region tour for information collection regarding tourism.

Table 5 shows the most impactful activity of tourists when using social media in the pre-trip stage of the tour process. The results reveal that in the pre-trip stage, a majority of tourists want to use social media to find and collaborate with travel party members (responded: 0.811).

Table 6 shows the social media behavior of tourists during the tour process while visiting the destinations. The results indicate that a majority of tourists want to use social media during the tour for self-expression (responded: 0.5838).

Table 7 shows the behavior of tourists when using social media after completing a rural mountain region tour. The results show that a majority of tourists want to use social media to keep in touch with travel party members after the trip (responded: 0.5744).

Table 8 shows the responses of tourists toward social media use throughout the entire process of tourism. The results show that $48.2 \%$ of tourists are of the view that they want to use social media in the planning stage of the tour, $22.86 \%$ want to use social media in the pre-trip stage of the tour before departure, $24.44 \%$ want to use social media during the trip, and only $4.5 \%$ want to use social media after completing the tour process.

\section{Conclusions and Future Study}

It is now possible to quantitatively measure tourist intentions to use social media in the tourism process, which was previously measured only by qualitative techniques. In this study, the ranking and weights of the matrices show that tourists use social media more in the planning stage of rural mountain region tourism (results of Table 8). The use of social media overall in rural mountain region tourism was very interesting through a quantitative study, since tourists like to use social media at rates of $48.2 \%$ in the planning stage, $22.86 \%$ in the pre-trip stage, $24.44 \%$ during the trip, and $4.5 \%$ after the trip. Therefore, this study contributes to the literature in the sense that it provides a mathematical and statistical equation/model to measure tourist intentions to use social media in the rural mountain region tour process. Future studies may be conducted to discern details about any stage of the tourism process, and tourist behavior can now be measured using a quantitative method. It is recommended that tourism-related agencies, whether they are government or private, should focus on the planning stage of tourism to influence tourist behavior toward rural mountain region tourism. Following on from previous literature that uses AHP, the mathematical models presented here can also be used for further measurement of the tourist intentions for a rural mountain region tourism [2]. 
In this study, four stages of using social media for rural mountain region tourism were discussed: the planning stage, pre-trip stage, during the trip stage, and post-trip stage. In all four stages of the trip, tourists used social media to handle trip affairs while touring rural mountain regions. The researcher attempted to establish the behavior of the tourists, and found that a majority mainly use social media in the planning stage of their rural mountain region trips.

These results also have a link to the existing literature in which some different results were found. In the literature, the researcher found that tourists residing in former Soviet Union republics used social media predominantly during the post-trip stage for sharing experiences and photos with friends and tour partners [72], while in this study, the results showed that only $4.5 \%$ of tourists wanted to use social media at the end of their trip.

Concerning the real situation in the tourism sector of Gilgit-Baltistan, Pakistan, there are many communication difficulties that tourists face while exploring these locations. Over the past few years, tourists have faced difficulties in booking hotel rooms when they arrive at their destinations [73]. The majority of hotels do not have online websites to provide suitable information for tourists in advance [74]. In another study, some researchers found that the inflow of international tourists to Gilgit-Baltistan was associated with regional and international festivals, as well as the current law and order in the country and region [75].

Based on the current situation in Gilgit-Baltistan and the links between the results of previous studies and the current study conducted by the researchers, it is recommended that the communication system of the region be updated, and all of the sources of information and advertisement for the promotion of tourism be made faster. Tourists will be more motivated if reliable online information is communicated on time. Another implication of these findings is for media, advertisers, and business operators involved with the tourism sector. These groups should focus on the planning stage of tourism if they want to attract tourists via social media.

The study largely focused on the local tourists who used social media and were motivated to visit a rural region; future research may include foreign tourists to achieve results with more generalizability. This study introduced the AHP model as a predictor of the tourist tour process. Future studies may be conducted to determine the details of any stage of the tourism process by quantitatively measuring tourist behavior.

Author Contributions: The first author (T.H.) contributed in writing original draft, conceptualization, data collection, formal analysis, and methodology. The second author (B.L.) and the third author (D.W.) contributed in analysis, review and edit the paper.

Funding: This research was sponsored and funded by National Social Science Fund of China (12\&ZD027) and State Administration of Radio and Television of China (GD11037).

Conflicts of Interest: The authors declare no conflicts of interest.

\section{References}

1. Saaty, T.L.; Peniwati, K. Group Decision Making: Drawing out and Reconciling Differences; RWS Publications: Pittsburgh, PA, USA, 2013.

2. Xue, K.; Deng, Y.; Wang, S. What factors influence national image in disaster reports? Evidence from China. Qual. Quant. 2015, 49, 1257-1265. [CrossRef]

3. Bozic, S.; Kennell, J.; Vujicic, M.D.; Jovanovic, T. Urban tourist motivations: Why visit ljubljana? Int. J. Tour. Cities 2017, 3, 382-398. [CrossRef]

4. Lim, Y.; Chung, Y.; Weaver, P.A. The impact of social media on destination branding: Consumer-generated videos versus destination marketer-generated videos. J. Vacat. Mark. 2012, 18, 197-206. [CrossRef]

5. Chen, C.-F. Applying the analytical hierarchy process (AHP) approach to convention site selection. J. Travel Res. 2006, 45, 167-174. [CrossRef]

6. Chen, L.; Ng, E.; Huang, S.-C.; Fang, W.-T. A self-evaluation system of quality planning for tourist attractions in taiwan: An integrated ahp-delphi approach from career professionals. Sustainability 2017, 9, 1751. [CrossRef] 
7. Vaidya, O.S.; Kumar, S. Analytic hierarchy process: An overview of applications. Eur. J. Oper. Res. 2006, 169, 1-29. [CrossRef]

8. Harrill, R. Residents' attitudes toward tourism development: A literature review with implications for tourism planning. J. Plan. Lit. 2004, 18, 251-266. [CrossRef]

9. Chen, Y.-C.; Yu, T.-H.; Tsui, P.-L.; Lee, C.-S. A fuzzy ahp approach to construct international hotel spa atmosphere evaluation model. Qual. Quant. 2014, 48, 645-657. [CrossRef]

10. Zhang, C.; Meadows C.W., III. International coverage, foreign policy, and national image: Exploring the complexities of media coverage, public opinion, and presidential agenda. Int. J. Commun. 2012, 6, 20.

11. Kaplan, A.M.; Haenlein, M. Users of the world, unite! The challenges and opportunities of social media. Bus. Horiz. 2010, 53, 59-68. [CrossRef]

12. Ellison, N.B. Social network sites: Definition, history, and scholarship. J. Comput.-Med. Commun. 2007, 13, 210-230.

13. Cox, C.; Burgess, S.; Sellitto, C.; Buultjens, J. The role of user-generated content in tourists' travel planning behavior. J. Hosp. Mark. Manag. 2009, 18, 743-764. [CrossRef]

14. Han, W.; McCabe, S.; Wang, Y.; Chong, A.Y.L. Evaluating user-generated content in social media: An effective approach to encourage greater pro-environmental behavior in tourism? J. Sustain. Tour. 2018, 26, 600-614. [CrossRef]

15. Xiang, Z. From digitization to the age of acceleration: On information technology and tourism. Tour. Manag. Perspect. 2017, 25, 147-150. [CrossRef]

16. Tam, D. Facebook by the numbers: 1.06 billion monthly active users. CNET News, 30 January 2013.

17. Chiu, C.; Ip, C.; Silverman, A. Understanding social media in china. McKinsey Q. 2012, 2, 78-81.

18. Linn, M. Technology and science education: Starting points, research programs, and trends. Int. J. Sci. Educ. 2003, 25, 727-758. [CrossRef]

19. Palvia, S.C.J.; Pancaro, R. Promises and perils of internet based networking. J. Glob. Inf. Technol. Manag. 2010, 13,1 .

20. Kohli, S.; Gupta, A. Modeling anonymous human behavior using social media. In Proceedings of the 9th International Conference for Internet Technology and Secured Transactions (ICITST-2014), London, UK, 8-10 December 2014; pp. 409-412.

21. Oravec, J.A. Bookmarking the world: Weblog applications in education. J. Adolesc. Adult Lit. 2002, 45, 616-621.

22. Liu, A. Tourism in rural areas: Kedah, malaysia. Tour. Manag. 2006, 27, 878-889. [CrossRef]

23. Briedenhann, J.; Wickens, E. Tourism routes as a tool for the economic development of rural areas-Vibrant hope or impossible dream? Tour. Manag. 2004, 25, 71-79. [CrossRef]

24. Greffe, X. Is rural tourism a lever for economic and social development? J. Sustain. Tour. 1994, 2, $22-40$. [CrossRef]

25. Hays, S.; Page, S.J.; Buhalis, D. Social media as a destination marketing tool: Its use by national tourism organisations. Curr. Issues Tour. 2013, 16, 211-239. [CrossRef]

26. Fotis, J.; Buhalis, D.; Rossides, N. Social Media Use and Impact during the Holiday Travel Planning Process; Springer: Berlin, Germany, 2012.

27. Rayman-Bacchus, L.; Molina, A. Internet-based tourism services: Business issues and trends. Futures 2001, 33, 589-605. [CrossRef]

28. Mangold, W.G.; Faulds, D.J. Social media: The new hybrid element of the promotion mix. Bus. Horiz. 2009, 52, 357-365. [CrossRef]

29. Kumar, P.; Kumar, V.; Mishra, J.M. Social media: A tool for tourism marketing. Int. Res. J. Bus. Manag.-IRJBM 2015, 3, 1-6.

30. Zeng, B.; Gerritsen, R. What do we know about social media in tourism? A review. Tour. Manag. Perspect. 2014, 10, 27-36. [CrossRef]

31. Vijayasarathy, L.R. Predicting consumer intentions to use on-line shopping: The case for an augmented technology acceptance model. Inf. Manag. 2004, 41, 747-762. [CrossRef]

32. Nadaraja, R.; Yazdanifard, R. Social Media Marketing: Advantages and Disadvantages; Center of Southern New Hempshire University: Kuala Lumpur, Malaysia, 2013.

33. Buhalis, D.; Law, R. Progress in information technology and tourism management: 20 years on and 10 years after the internet-The state of etourism research. Tour. Manag. 2008, 29, 609-623. [CrossRef] 
34. Gretzel, U.; Yoo, K.H. Use and impact of online travel reviews. Inf. Commun. Technol. Tour. 2008, 2008, 35-46.

35. Buhalis, D.; Jun, S.H. E-tourism. Contemp. Tour. Rev. 2011, 1, 1-38.

36. Radosevich, L. Fixing web-site usability. InfoWorld 1997, 19, 81-82.

37. Pan, B.; Fesenmaier, D.R. Online information search: Vacation planning process. Ann. Tour. Res. 2006, 33, 809-832. [CrossRef]

38. Munar, A.M.; Jacobsen, J.K.S. Motivations for sharing tourism experiences through social media. Tour. Manag. 2014, 43, 46-54. [CrossRef]

39. Price, M.F.; Jansky, L.; Iatsenia, A.A. Key Issues for Mountain Areas; United Nations University Press: Tokyo, Japan, 2004.

40. Baltes, B.B.; Dickson, M.W.; Sherman, M.P.; Bauer, C.C.; LaGanke, J.S. Computer-mediated communication and group decision making: A meta-analysis. Organ. Behav. Hum. Decis. Process. 2002, 87, 156-179. [CrossRef]

41. Beaudoin, C.E.; Thorson, E. Social capital in rural and urban communities: Testing differences in media effects and models. J. Mass Commun. Q. 2004, 81, 378-399. [CrossRef]

42. Davidson, T.L. What are travel and tourism: Are they really an industry. Glob. Tour. 1998, 3, 447-475.

43. Nei, C.J.-C. Tourism as a Strategy for the Urban Development of Small Towns; McGill University: Montreal, QC, Canada, 2010.

44. Scott, D.; Lemieux, C. Weather and Climate Information for Tourism. Available online: https://www. sciencedirect.com/science/article/pii/S1878029610000125 (accessed on 13 June 2018).

45. Bonham, C.; Mak, J. The Growing Importance of Tourism in the Global Economy and International Affairs. Available online: https: / www.georgetownjournalofinternationalaffairs.org/online-edition/the-growingimportance-of-tourism-in-the-global-economy-and-international-affairs (accessed on 13 June 2018).

46. Heeley, J. The definition of tourism in great britain: Does terminological confusion have to rule? Tour. Rev. 1980, 35, 11-14. [CrossRef]

47. Leiper, N. The framework of tourism: Towards a definition of tourism, tourist, and the tourist industry. Ann. Tour. Res. 1979, 6, 390-407. [CrossRef]

48. Cohen, E. Who is a tourist?: A conceptual clarification. Sociol. Rev. 1974, 22, 527-555. [CrossRef]

49. Fadairo, O.O.; Ajala, A.O. International Tourist Attraction Potentials of Local Ceramics Cottage Production in Nigeria. Available online: http:/ / www.ijsch.com/journaluk/images/frontImages/INTERNATIONAL_ TOURIST_ATTRACTION.pdf (accessed on 13 June 2018).

50. Maleki, P. 3s'tourism Image and Its Determining Factors: Evidence from North Cyprus; Eastern Mediterranean University (EMU)-Doğu Akdeniz Üniversitesi (DAÜ): İsmet İnönü Bulvarı, Gazimağusa, 2015.

51. Oliver, T.; Jenkins, T. Integrated tourism in europe's rural destinations: Competition or cooperation. In Tourism SMEs, Service Quality and Destination Competitiveness, CABI International; CABI Publishing: Oxfordshire, UK, 2005; pp. 25-39.

52. Hall, D.; Roberts, L.; Mitchell, M. New Directions in Rural Tourism; Ashgate Publishing Ltd.: Farnham, UK, 2003.

53. Oppermann, M. Rural tourism in southern germany. Ann. Tour. Res. 1996, 23, 86-102. [CrossRef]

54. Frochot, I. A benefit segmentation of tourists in rural areas: A scottish perspective. Tour. Manag. 2005, 26, 335-346. [CrossRef]

55. Sharpley, R.; Sharpley, J. Rural Tourism. An Introduction. Available online: https://books.google.ch/books/ about/Rural_Tourism.html?id=E0EaAQAAMAAJ\&redir_esc=y (accessed on 13 June 2018).

56. Daugstad, K. Negotiating landscape in rural tourism. Ann. Tour. Res. 2008, 35, 402-426. [CrossRef]

57. AfroMont. What is A Mountain? 2016. Available online: http://mri.scnatweb.ch/en/african-mountains / 2014-04-30-14-38-33 (accessed on 12 March 2017).

58. WIKIAlps. Mountain and Mountain Area. 2018. Available online: http://www.wikialps.eu/doku.php?id= wiki:mountain_and_mountain_area (accessed on 23 January 2018).

59. Leung, D.; Law, R.; Van Hoof, H.; Buhalis, D. Social media in tourism and hospitality: A literature review. J. Travel Tour. Mark. 2013, 30, 3-22. [CrossRef]

60. Burgess, S.; Sellitto, C.; Cox, C.; Buultjens, J. User-Generated Content (UGC) in Tourism: Benefits and Concerns of Online Consumers. Available online: https:/ / epubs.scu.edu.au/comm_pubs/278/ (accessed on 13 June 2018). 
61. U.S. Library of Congress. Pakistan Geography Us Country Studies. 2008. Available online: http:// countrystudies.us/pakistan/23.htm (accessed on 18 January 2018).

62. Imran, S. Tourism Development in Gilgit Baltistan, Situation Analysis and Investment Opportunities. 2017. Available online: http:/ / www.gilgitbaltistan.gov.pk/DownloadFiles/InvestmentPotential/Tourism.pdf (accessed on 1 March 2018).

63. Weightman, B.A. Dragons and Tigers: A Geography of South, East, and Southeast Asia; John Wiley and Sons: Hoboken, NJ, USA, 2011.

64. City Population. Population Statistics for Countries. 2017. Available online: http://www.citypopulation.de/ GilgitBaltistan.html (accessed on 18 January 2018).

65. Hussain, T.; Abbas, J.; Li, B.; Aman, J.; Ali, S. Natural resource management for the world's highest park: Community attitudes on sustainability for central karakoram national park, pakistan. Sustainability 2017, 9, 972. [CrossRef]

66. Imran, S.; Alam, K.; Beaumont, N. Environmental orientations and environmental behaviour: Perceptions of protected area tourism stakeholders. Tour. Manag. 2014, 40, 290-299. [CrossRef]

67. Martin, D.; Woodside, A.G. Structure and process modeling of seemingly unstructured leisure-travel decisions and behavior. Int. J. Contemp. Hosp. Manag. 2012, 24, 855-872. [CrossRef]

68. Marine-Roig, E.; Martin-Fuentes, E.; Daries-Ramon, N. User-generated social media events in tourism. Sustainability 2017, 9, 2250. [CrossRef]

69. Kang, M.; Schuett, M.A. Determinants of sharing travel experiences in social media. J. Travel Tour. Mark. 2013, 30, 93-107. [CrossRef]

70. Saaty, T.L. The Analytic Hierarchy Process; McGraw-Hill: New York, NY, USA, 1980.

71. Fotis, J.; Buhalis, D.; Rossides, N. Social media impact on holiday travel planning: The case of the russian and the fsu markets. Int. J. Online Mark. (IJOM) 2011, 1, 1-19. [CrossRef]

72. Rehman, M. Tourism in G-B Experiences Revival this Year. 2015. Available online: https://tribune.com.pk/ story/982315/into-the-valley-tourism-in-g-b-experiences-revival-this-year/ (accessed on 18 July 2017).

73. Ahmed, R.; Mahmood, K. Tourism potential and constraints: An analysis of tourist spatial attributes in pakistan. Pak. Perspect. 2018, 22, 2.

74. Hunzai, I. Conflict Dynamics in Gilgit-Baltistan; United States Institute of Peace: Washington, DC, USA, 2013.

75. Grieser, A.; Sökefeld, M. Intersections of Sectarian Dynamics and Spatial Mobility in Gilgit-Baltistan; EB-Verlag: Berlin, Germany, 2015. 